\title{
DEVELOPING A SUSTAINABLE BUSINESS EXCELLENCE MODEL AND DISCUSSING KEY FACTORS
}

\author{
P.H. Fan ${ }^{1 \# *} \&$ W.L. Chang ${ }^{1}$
}

\section{ARTICLE INFO}

Article details

Submitted by authors 6 Aug 2020

Accepted for publication 29 Mar 2021

Available online $\quad 28$ May 2021

\section{Contact details}

Corresponding author

garyfan1688@gmail.com

\section{Author affiliations}

1 College of Management, National Taipei University of Technology,

Taiwan, Republic of China

\# The author was enrolled for an $\mathrm{PhD}$ degree in the College of Management, National Taipei University of Technology, Taiwan, Republic of China

\section{ORCID® identifiers}

P.H. Fan

https: / /orcid.org/0000-0002-7693-2301

W.L. Chang

https://orcid.org/0000-0001-7985-3580

DOI

http://dx.doi.org/10.7166/32-1-2397

\section{ABSTRACT}

To achieve sustainable growth and maintain competitive advantages, many companies consider the sustainability of society and the environment, and adopt the business excellence (BE) framework of quality awards to promote total quality management (TQM) activities. This study used the Malcolm Baldrige National Quality Award's (MBNQA) business excellence evaluation standard as the main body, supplemented by the Dow Jones Sustainability Indexes (DJSI). It proposed scoring criteria for the sustainable business excellence model, and discussed the degree of cause and correlation between evaluation criteria. The key factors were explored to provide companies with a reference for the pursuit of sustainable business excellence.

\section{OPSOMMING}

Baie maatskappye oorweeg die volhoubaarheid van die samelewing en die omgewing om volhoubare groei te behaal en mededingendheid te behou. Sodoende aanvaar hulle die besigheidsuitnemendheid riglyn van gehalte toekennings om totale gehaltebestuur aktiwiteite te bevorder. Hierdie studie het die Malcolm Baldrige nasionale gehalte toekennings se kriteria vir besigheidsuitnemendheid gebruik. Hierdie kriteria is aangevul deur die Dow Jones volhoubaarheidsindekse. Tellingkriteria is aan die hand hiervan voorgestel en die graad van oorsaak en korrelasie tussen evalueringskriteria is bespreek. Die sleutelfaktore is ondersoek om maatskappye met ' $\mathrm{n}$ verwysing vir die nastrewing van volhoubare besigheidsuitnemendheid te verskaf.

In the past two decades, as environmental climate change and social responsibility have received increased attention, business organisations have proposed responses in their operations that have produced good results. IBM, Alcoa, and Wal-Mart have all saved on high expenses through energysaving and waste-reduction activities. Ford Motor Company is using new technology in the assembly line process to reduce $\mathrm{CO}_{2}$ emissions by $15 \%$, volatile organic compounds (VOCs) by $10 \%$, and operating time by $20 \%$ [1]. In addition to pursuing profit, Toyota Motor Corporation is also actively looking for opportunities to improve its social and environmental impacts, and has developed hybrid vehicles, which have increased its brand value by $47 \%$ [2]. These examples demonstrate the advantages of the sustainable development of enterprises and enable investors, shareholders, consumers, the general public, and other stakeholders to accept these enterprises. In the new economic generation of high technology, enterprises must achieve a balance between economic development and maintaining civilisation and natural harmony to have the possibility of sustainable survival [3]. The market value of an enterprise is no longer measured solely by the economic dimension, but rather is evaluated by the performance of the triple bottom line (TBL), which is based on integrating economic, environmental, and social dimensions [4]. Each measurement factor changes with the other and with time, and each requires continuous monitoring [5].

Socially responsible investment (SRI) generates financial and social benefits by integrating social justice, environmental sustainability, and financial performance in the investment process. According to the statistics of the Asian Sustainable Investment Association in 2014, SRI Funds in Asia have climbed 
year by year, there are 500 tranches with an asset size of USD 44.9 billion to invest, and integrates environmental, social, and governance issues, and experienced a growth of $22 \%$ in the past three years(2011 2013). Among those funds, funds related to sustainable issues have grown the fastest. Financial performance is no longer the only consideration for investors; corporate governance, corporate responsibility, and issues of social concern have become considerations for investment decisions. SRI market statistics show that social responsibility involves consideration of a wide range of issues and of the entire range of funds.

There are numerous management theories on organisational and business management issues. Total quality management (TQM) and business excellence (BE) are the most popular approaches for companies to improve performance and achieve outstanding high-quality performance [6-7]. In the 1980s, the United States systematically conceptualised TQM as a standard structure for BE to provide businesses with tools to implement self-assessment and continuous improvement. The implementation of superior quality management is conducive to the practice of socially responsible actions (both environmental and social), and it is necessary for companies to incorporate social and environmental issues into their organisational strategies and operations when establishing a corporate social responsibility culture [8-9]. Therefore, with the current fermentation in sustainability issues, corporate organisations should promote corporate social responsibility goals and practices in a timely manner and integrate them into their business management systems, so that the organisational culture can be naturally generated [10-12], thus promoting not only the development of socially responsible activities [11], but also environmental management [13].

Therefore this study integrated corporate sustainability into the business excellence model so that companies can enjoy sustainable development while gaining operating profit. Specifically, the research objectives of this study included the following:

(1) To consolidate internationally well-known social responsibility investment indicators and business excellence model frameworks through a literature review, and to identify evaluation measurement indicators with suitability and consistency according to experts and scholars from industry, academia, and research, and then construct a system architecture that reflects sustainable business excellence operation.

(2) To discuss the key factors by constructing a sustainable business excellence model, so that business organisations can accurately grasp the direction of sustainable operation.

\section{SUSTAINABLE ENTERPRISE DEVELOPMENT}

The United Nations' World Commission on Environment and Development put forward the following definition of sustainable development in its 1987 report entitled "Our common future: A development model that can meet our current needs without compromising future generations to meet their needs". However, the process of sustainably developing an enterprise is also based on basic waste disposal, pollution control, and recycling, which then evolves into the triple bottom line of corporate social responsibility and economic, social, and environmental integration [14], as seen in Figure 1. The World Business Council for Sustainable Development (WBCSD) also explained that the sustainable development responsibilities of enterprises cover the three responsibilities of finance, environmental protection, and society (Figure 2). A sustainable enterprise must rely on economic, social, and environmental benefits to promote sustainable development [15]. When sustainable enterprises work to meet the needs of their direct or indirect stakeholders, they will not jeopardise their ability to meet the needs of future stakeholders [16]. Therefore, if companies want to achieve sustainable development goals, they must take environmental and economic costs into consideration at the same time. Although it is easier to achieve short-term economic goals, in the long run, the ' $t$ ' goal of the triple bottom line can only be achieved when social, environmental, and economic sustainability are all successful. 


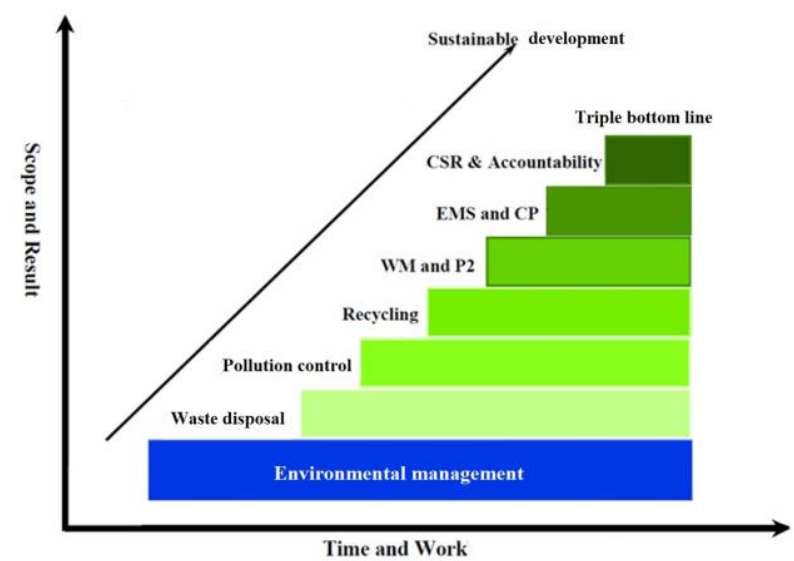

Figure 1: Development process of a company's sustainable development

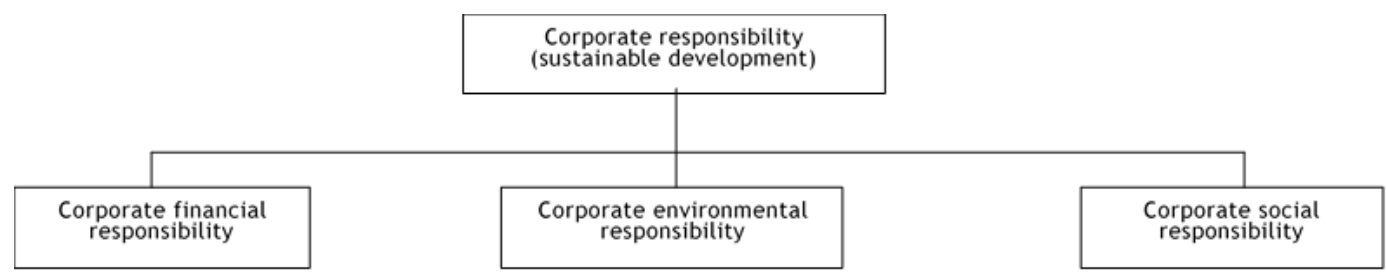

Figure 2: Relationship between corporate social responsibility and sustainable development

\section{SOCIALLY RESPONSIBLE INVESTMENT AND RATING INDICATORS}

The concept of SRI can be traced back to the 17th century, when the Christian Church refused to invest in arms and slavery and chose to invest in enterprises that practised ethics and social equity and implemented environmental protection. In the early 21st century, the development of SRI proved that the value of the capital market had undergone tremendous changes, and that people had begun to pay attention to corporate TBL and the creation of long-term value. In 2005, the United Nations invited large global institutional investors to participate in formulating and adopting the principle of responsible investment, which integrated the sustainability issues of environmental and social corporate governance (ESG) into investment strategies as a norm for SRI. Investors are attracted by the sustainability performance of a company because it has grasped the business opportunities from the economic, environmental, and social development stages, and can show investors that it can create long-term value. In the foreseeable future, the pursuit of sustainable development will become the main boost for SRI performance [17]. The Dow Jones sustainability indexes (DJSI) series is the bestknown index in global SRI development. Specific indicators are based on the three major dimensions of economy, environment, and society, and the content and weights are adjusted according to different industries (Table 1). This study used this sustainability evaluation index as its research benchmark.

Table 1: Dow Jones sustainability indexes

\begin{tabular}{|c|c|c|c|}
\hline Dimension & Item & Dimension & Item \\
\hline \multirow{4}{*}{ Economic } & Corporate governance & \multirow{6}{*}{ Social } & Human capital development \\
\hline & Risk and crisis management & & Corporate citizenship/charity \\
\hline & $\begin{array}{l}\text { Company system/execution/ } \\
\text { corruption and fraud }\end{array}$ & & $\begin{array}{l}\text { Attractiveness to professionals and } \\
\text { stability of staff }\end{array}$ \\
\hline & Industry-specific items & & Workforce practice indicators \\
\hline \multirow{2}{*}{ Environmental } & Environmental report & & Social report \\
\hline & Industry-specific items & & Industry-specific items \\
\hline
\end{tabular}


In an environment of increasingly fierce global competition, all industries are actively promoting various improvement plans. Since the 1990s, companies have mostly adopted the BE framework of quality awards as the operational framework for organisations to promote TQM activities [6-7][18]. Many scholars also believe that these business excellence models are the operational framework for TQM activities [18-21]. The Malcolm Baldrige National Quality Award (MBNQA) BE framework (Figure 3 ) is recognised worldwide as a model for business innovation. According to statistics from the United States Department of Commerce, more than 60 countries around the world use MBNQA as a standard for judging outstanding performance in order to improve the competitiveness of a country's enterprises [22]. The European Excellence Model was influenced by MBNQA. It was created by the European Foundation for Quality Management in the early 1990s, and then updated in response to feedback from foundation members, companies, and users. This excellence model is divided into nine major items, emphasising the need for continuous innovation and learning. In 1995, the Socio-Economic Productivity Center of the Japanese Foundation also used MBNQA as a blueprint to build Japan's standards of business excellence model based on a customer focus, special capabilities, high-quality employees, and the development of a harmonious social relationship. The current study integrated the content of these three types of business excellence model as benchmarks for the research indicators.

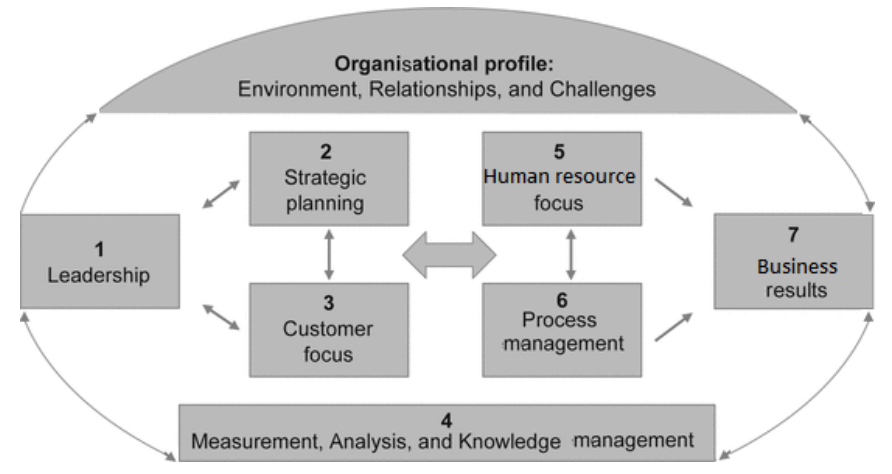

Figure 3: US national quality award architecture

\section{DEVELOPING A SUSTAINABLE BUSINESS EXCELLENCE ARCHITECTURE AND INDICATORS}

Based on the above-mentioned US, European, and Japanese BE frameworks and DJSI, a total of 61 indicators (Table 2) were initially planned for the subsequent research. Through the correlation and difference analysis of various excellence models, it was found that MBNQA is used most often [6-7][18], and that it has been integrated into the sustainable development concept to a considerable extent, to include the economic, environmental, and social dimensions. However, there are still shortcomings. This study has integrated them into the initial framework, adding 10 indicators (those that are marked with '*').

Table 2: Comparison of indicators, and references, for sustainable business excellence model

\begin{tabular}{|l|l|l|}
\hline Architecture & Indicator & References \\
\hline Leadership and governance & $\begin{array}{l}\text { Formulate the organisation's clear development vision, } \\
\text { values and mission, and organisational culture }\end{array}$ & $1,2,3,4$ \\
\cline { 2 - 3 } & ${ }^{*}$ Clarify the organisation's sustainability policy & 4 \\
\cline { 2 - 3 } Senior leadership & $\begin{array}{l}\text { Establish an internal and external multi-channel } \\
\text { communication model }\end{array}$ & 1,2 \\
\cline { 2 - 3 } & $\begin{array}{l}\text { Strengthen operating performance to achieve a balanced } \\
\text { value between customers and stakeholders }\end{array}$ & 1,2 \\
\cline { 2 - 3 } & $\begin{array}{l}\text { * Competitive investment returns of capital providers and } \\
\text { protection of company assets }\end{array}$ & 2,4 \\
\hline \multirow{3}{*}{$\begin{array}{l}\text { Governance and social } \\
\text { responsibility }\end{array}$} & $\begin{array}{l}\text { The organisation has clear management responsibilities } \\
\text { with diversity in its members }\end{array}$ & $1,3,4$ \\
\cline { 2 - 3 } & $\begin{array}{l}\text { Robust finance, transparent operation, and independent } \\
\text { audit system }\end{array}$ & $1,3,4$ \\
\hline
\end{tabular}




\begin{tabular}{|c|c|c|}
\hline Architecture & Indicator & References \\
\hline & $\begin{array}{l}\text { The organisation operates in compliance with laws and } \\
\text { regulations, as well as environmental protection } \\
\text { regulations }\end{array}$ & $1,3,4$ \\
\hline & $\begin{array}{l}\text { Formulate an ethical code of conduct for anti-corruption } \\
\text { and bribery }\end{array}$ & $1,2,3,4$ \\
\hline & $\begin{array}{l}\text { Organise the establishment of social responsibility } \\
\text { awareness and participation in activities for all, and } \\
\text { support and improve the relevant communities }\end{array}$ & $1,2,3,4$ \\
\hline & $\begin{array}{l}\text { * Fair trade with suppliers, distributors, and business } \\
\text { partners }\end{array}$ & 2,4 \\
\hline & $\begin{array}{l}\text { * Promote, supervise, and maintain the standards to be } \\
\text { followed when dealing with all stakeholders }\end{array}$ & 2,4 \\
\hline \multicolumn{3}{|l|}{ Strategic planning } \\
\hline \multirow[b]{2}{*}{ Strategy development } & The organisation has a set of strategic planning processes & $1,2,3$ \\
\hline & $\begin{array}{l}\text { It has clear strategic goals, schedules, and setting } \\
\text { methods }\end{array}$ & $1,2,3$ \\
\hline \multirow{3}{*}{ Strategy execution } & $\begin{array}{l}\text { The realisation strategy has the action plan development } \\
\text { content, goals, and resources required for execution, as } \\
\text { well as authority and responsibility units }\end{array}$ & $1,2,3$ \\
\hline & There is a future performance estimate & 1,2 \\
\hline & $\begin{array}{l}\text { Scan the industrial environment to identify risk } \\
\text { predictions and crisis management response content }\end{array}$ & $1,2,3,4$ \\
\hline \multicolumn{3}{|l|}{ Customer focus } \\
\hline \multirow{3}{*}{ Customer voice } & $\begin{array}{l}\text { The organisation has a set of methods to listen to the } \\
\text { voices of its customers and grasp the needs and } \\
\text { expectations of customers and markets }\end{array}$ & $1,2,3$ \\
\hline & $\begin{array}{l}\text { There are methods to accept customer complaints and } \\
\text { opinions, and measurement benchmarks to ensure } \\
\text { customer satisfaction and participation }\end{array}$ & $1,2,3$ \\
\hline & $\begin{array}{l}{ }^{*} \text { Respect customers and provide the highest level of } \\
\text { product and service value }\end{array}$ & 2,4 \\
\hline \multirow{3}{*}{ Customer loyalty } & $\begin{array}{l}\text { Product sales provide a way to meet needs and obtain } \\
\text { customer support and participation }\end{array}$ & 1,2 \\
\hline & $\begin{array}{l}\text { Establish customer relationship management methods to } \\
\text { maintain and improve customer loyalty and market share }\end{array}$ & $1,2,3,4$ \\
\hline & ${ }^{*}$ Brand management and operation & 4 \\
\hline \multicolumn{3}{|c|}{ Measurement, analysis, and knowledge management } \\
\hline \multirow{4}{*}{$\begin{array}{l}\text { Measuring, analysing, and } \\
\text { improving performance }\end{array}$} & $\begin{array}{l}\text { The organisation has systematic operation performance } \\
\text { evaluation procedures }\end{array}$ & $1,2,4$ \\
\hline & $\begin{array}{l}\text { * The organisation evaluates its environmental impact and } \\
\text { conducts environmental life cycle analysis and design } \\
\text { according to the organisation's context }\end{array}$ & 4 \\
\hline & Performance analysis and review & 1,2 \\
\hline & Perform performance improvement activities & 1,2 \\
\hline \multirow{2}{*}{$\begin{array}{l}\text { Management of data, knowledge, } \\
\text { and information technology }\end{array}$} & $\begin{array}{l}\text { Data information, intelligence data, and professional } \\
\text { knowledge management }\end{array}$ & $1,2,3$ \\
\hline & $\begin{array}{l}\text { Information sources and information technology } \\
\text { management }\end{array}$ & 1,3 \\
\hline \multicolumn{3}{|l|}{ Employee focus } \\
\hline \multirow{2}{*}{ Working environment } & Attach importance to employee functions and abilities & $1,2,3,4$ \\
\hline & Create a positive working atmosphere & $1,2,3$ \\
\hline \multirow{3}{*}{ Employee centripetal force } & Staff performance & $1,2,3,4$ \\
\hline & Evaluation of employee centripetal force & $1,2,3,4$ \\
\hline & Workforce development and leadership training & $1,2,3,4$ \\
\hline \multicolumn{3}{|l|}{ Operation management } \\
\hline \multirow{5}{*}{ Operating system } & Operating system design & 1,3 \\
\hline & Operating system management & 1,3 \\
\hline & $\begin{array}{l}\text { * Life cycle cost management and environmental design } \\
\text { during R\&D and the production of products/services }\end{array}$ & 3,4 \\
\hline & * Carry out energy saving and emission reduction activities & 4 \\
\hline & Emergency response capability & 1 \\
\hline \multirow{2}{*}{ Work flow } & Work flow design & 1,3 \\
\hline & Operation process management & 1,3 \\
\hline \multicolumn{3}{|l|}{ Results } \\
\hline & Quality of products/services provided & 1,2 \\
\hline
\end{tabular}




\begin{tabular}{|c|c|c|}
\hline Architecture & Indicator & References \\
\hline \multirow{3}{*}{$\begin{array}{l}\text { Evaluation results of customer- } \\
\text { focused products and work } \\
\text { processes }\end{array}$} & Cost of providing products/services & 1,2 \\
\hline & Delivery of products/services & 1,2 \\
\hline & Flexibility in providing products/services & 1,2 \\
\hline \multirow{2}{*}{$\begin{array}{l}\text { Evaluation results of operating } \\
\text { process efficiency }\end{array}$} & Operational efficiency & 1 \\
\hline & Emergency preparedness & 1 \\
\hline $\begin{array}{l}\text { Evaluation results of strategy } \\
\text { execution }\end{array}$ & Strategy and action plan & 1,3 \\
\hline \multirow{2}{*}{$\begin{array}{l}\text { Evaluation results of customer } \\
\text { relationship management } \\
\text { performance }\end{array}$} & Customer satisfaction & $1,2,3$ \\
\hline & Customer loyalty & 1,2 \\
\hline \multirow{4}{*}{$\begin{array}{l}\text { Evaluation results of workforce } \\
\text { management performance }\end{array}$} & Staff functions and capabilities & $1,3,4$ \\
\hline & Staff working atmosphere & $1,2,3$ \\
\hline & Employee centripetal force & $1,2,3,4$ \\
\hline & Employee development & $1,2,3,4$ \\
\hline \multirow{5}{*}{$\begin{array}{l}\text { Evaluation results of leadership, } \\
\text { governance, and social } \\
\text { responsibility performance }\end{array}$} & Leadership & $1,3,4$ \\
\hline & Governance & $1,3,4$ \\
\hline & Laws and regulations & $1,3,4$ \\
\hline & Ethics & $1,3,4$ \\
\hline & * Social and environmental reports & 4 \\
\hline \multirow{2}{*}{$\begin{array}{l}\text { Evaluation results of financial and } \\
\text { market performance }\end{array}$} & Financial performance & $1,2,3$ \\
\hline & Market performance & $1,2,3$ \\
\hline No. & \multicolumn{2}{|l|}{ References } \\
\hline 1 & \multicolumn{2}{|c|}{ 2013 2014 criteria for performance excellence, 2013 (NIST) [23] } \\
\hline 2 & \multicolumn{2}{|c|}{$\begin{array}{l}\text { The EFQM excellence model to assess organisational performance }-A \\
\text { management guide (best practice), } 2007 \text { [24] }\end{array}$} \\
\hline 3 & \multicolumn{2}{|c|}{ Japan Quality Award assessment guide book, 2008 [25] } \\
\hline 4 & \multicolumn{2}{|c|}{$\begin{array}{l}\text { DJSI http://www.sustainability-indexes.com/dow-jones-sustainability- } \\
\text { indexes [26] }\end{array}$} \\
\hline
\end{tabular}

\section{RESEARCH DESIGN}

The main purpose of this research was to construct a set of investment index frameworks that combined sustainable development and business excellence, and to discover the key success factors. Therefore the questionnaire survey was divided into two stages. The first stage used the fuzzy Delphi expert questionnaire to establish the design model; the second stage used the decision-making trial and evaluation laboratory (DEMATEL) to explore the key index.

\subsection{Fuzzy Delphi method}

This study adopted the modified fuzzy Delphi method (FDM) [27] as its basis, and used the double triangle fuzzy number to obtain expert consensus on the importance value $G^{i}$. The gray zone test was used to test whether the experts' cognition showed a consistent convergence. The implementation steps were as follows:

Step 1: Give a possible interval value for each fuzzy expert questionnaire measurement item. The minimum of this interval value indicates the most conservative cognitive value of the measurement item, and the maximum indicates the most optimistic cognitive value.

Step 2: Collect the most conservative cognitive value and the most optimistic cognitive value given by the interviewee for each measurement item; exclude extreme values that fall outside the double standard deviation; and then calculate the minimum $C_{L}^{i}$, geometric mean $C_{M}^{i}$, and maximum $C_{U}^{i}$ in the most conservative cognitive values that remain, as well as the minimum $O_{L}^{i}$, geometric mean $O_{M}^{i}$, and maximum $O_{U}^{i}$ in the most optimistic cognitive values that remain.

Step 3: Establish the triangular fuzzy number $C^{i}=\left(C_{L}^{i}, C_{M}^{i}, C_{U}^{i}\right)$ of the most conservative cognition and the triangular fuzzy number $O^{i}=\left(O_{L}^{i}, O_{M}^{i}, O_{U}^{i}\right)$ of the most optimistic cognition in each measurement item $\mathrm{i}$ respectively (Figure 4).

Step 4: Check whether the opinions of the experts have reached consensus by the following methods: 
If there is no overlap between the two triangular fuzzy numbers $\left(C_{U}^{i} \leqq O_{L}^{i}\right)$, it means that each expert's opinion interval value has a consensus section, and the opinion tends to be within the scope of this consensus section. Therefore, let the consensus importance value $G^{i}$ of measurement item i be equal to the arithmetic mean of $C_{M}^{i}$ and $O_{M}^{i}$ (see Eq. 1 for the calculation equation):

$$
G^{i}=\frac{C_{M}^{i}+O_{M}^{i}}{2}
$$

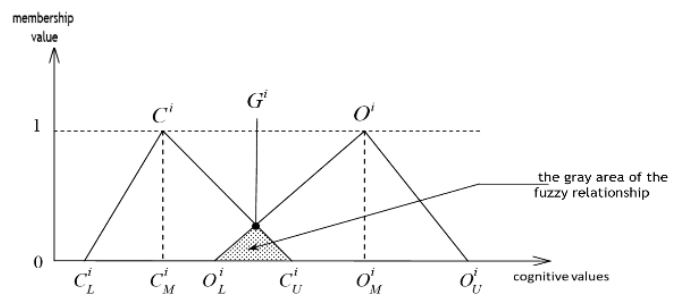

Figure 4: Schematic diagram of double triangle fuzzy number

If the fuzzy numbers of the two triangles overlap - that is, $\left(C_{U}^{i}>O_{L}^{i}\right)$, and the grey area $Z^{i}=C_{U}^{i}-O_{L}^{i}$ of the fuzzy relationship is smaller than the interval $M^{i}=O_{M}^{i}-C_{M}^{i}$ between the geometric average of the optimistic cognition and the geometric average of the conservative cognition by the experts on this measurement item - it means that, although there is no consensus between the opinions of each expert, the two experts with extreme opinions (the minimum for optimistic cognition and the maximum for conservative cognition) do not differ greatly from the opinions of other experts, leading to divergent opinions. Therefore, let the consensus importance value $G^{i}$ of measurement item i be equal to the fuzzy set obtained by performing the intersection ( $\mathrm{min}$ ) operation on the fuzzy relationship of the two triangular fuzzy numbers, and then find the quantitative score of the fuzzy set with the maximum membership value (see Eq. 2 for the calculation equation):

$$
G^{i}=\frac{\left[\left(C_{U}^{i} \times O_{M}^{i}\right)-\left(O_{L}^{i} \times C_{M}^{i}\right)\right]}{\left[\left(C_{U}^{i}-C_{M}^{i}\right)+\left(O_{M}^{i}-O_{L}^{i}\right)\right]}
$$

If the fuzzy numbers of the two triangles overlap - that is, $\left(C_{U}^{i}>O_{L}^{i}\right)$, and the grey area $Z^{i}=C_{U}^{i}-O_{L}^{i}$ of the fuzzy relationship is larger than the interval between $M^{i}=O_{M}^{i}-C_{M}^{i}$ of the optimistic geometric mean value and the conservative geometric mean value from the experts on this measurement item - it means that there is no consensus between the opinions of the experts, and the two experts with extreme opinions (the minimum for optimistic cognition and the maximum for conservative cognition) vary greatly from the opinions of other experts, and thus opinion divergence will occur. Therefore the conservative cognitive minimum $C_{L}^{i}$, geometric average $C_{M}^{i}$, maximum $C_{U}^{i}$, optimistic cognitive minimum ${ }^{O_{L}^{i}}$, geometric average $O_{M}^{i}$, and maximum $O_{U}^{i}$ of these measurement items that have not converged will be provided to the experts for reference. Steps 1 to 4 are then repeated for the next questionnaire survey until all measurement items have reached convergence and the consensus importance value $G^{i}$ is obtained.

\subsection{Decision-making trial and evaluation laboratory}

DEMATEL can explore the interdependence of various criteria to solve complex causal relationships, improve the understanding of special problems, and identify a feasible solution through a hierarchical structure. In recent years it has been widely used to solve various types of complex and entangled problems [28]. The DEMATEL method first determines the indicators according to decision factors, and forms a questionnaire for decision-makers to fill in, and then integrates the content of the questionnaire from each decision-maker, establishes a direct relationship matrix of the index factors, and forms a direct and indirect relationship matrix of the index after matrix calculation. Next it calculates the total correlation degree and cause degree and, finally, draws an influential network relation map (INRM). 


\subsection{Questionnaire design}

\subsubsection{Fuzzy Delphi expert questionnaire}

A fuzzy interval value of 0 to 10 points was given in the evaluation method of each criterion question. The minimum of this interval value indicated the most conservative cognitive value, and the maximum indicated the most optimistic cognitive value. A higher score indicated that the measurement item was more important. An open suggestion bar was designed to provide opinions on various indicators to supplement the insufficient content of the questionnaire (Table 3).

Table 3: Fuzzy Delphi expert questionnaire design example

\begin{tabular}{|c|c|c|c|c|}
\hline \multirow{2}{*}{ Criteria item } & \multirow{2}{*}{$\begin{array}{c}\text { Degree of } \\
\text { importance } \\
\text { Most likely value } \\
(0-10)\end{array}$} & \multicolumn{2}{|c|}{ Acceptable range } & \multirow{2}{*}{ Amendments } \\
\hline & & $\begin{array}{l}\text { Acceptable } \\
\text { minimum }\end{array}$ & $\begin{array}{l}\text { Acceptable } \\
\text { maximum }\end{array}$ & \\
\hline $\begin{array}{l}\text { Clarify the organisation } \\
\text { sustainability policy }\end{array}$ & 9 & 7 & 10 & \\
\hline
\end{tabular}

\subsubsection{DEMATEL questionnaire}

The DEMATEL questionnaire was used to evaluate the impact of the criteria of each dimension and evaluate the interdependence of each pair (Table 4).

Table 4: DEMATEL questionnaire design example

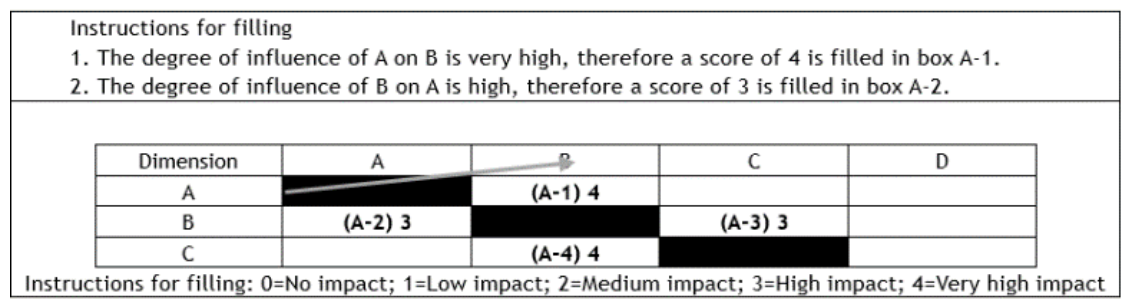

\subsection{Questionnaire respondents}

Because companies mainly pursue financial performance, the combination with sustainable development has not been widely discussed. Therefore the respondents needed to have professional knowledge and practical experience to provide in-depth and accurate opinions. A total of seven experts were invited to answer the questionnaire in this study: three from industry, two from academia, and two from research institutions (Table 5).

Table 5: Respondents' background

\begin{tabular}{|c|c|c|c|}
\hline & Unit attribute & Job title & Explanation \\
\hline 1 & Technology company & Chairman & Taiwan NQA (TNQA) reviewer \\
\hline 2 & Technology company & Vice President & TNQA reviewer \\
\hline 3 & Accounting firm & Senior manager & TNQA reviewer \\
\hline 4 & $\begin{array}{l}\text { Colleges and } \\
\text { universities }\end{array}$ & Professor & TNQA reviewer \& chairman of Chinese Society for Quality \\
\hline 5 & $\begin{array}{l}\text { Colleges and } \\
\text { universities }\end{array}$ & Professor & TNQA reviewer \\
\hline 6 & Research institute & Team leader & $\begin{array}{l}\text { Head of TNQA committee, Bureau of Industry, Ministry of } \\
\text { Economic Affairs }\end{array}$ \\
\hline 7 & Research institute & $\begin{array}{l}\text { Technical } \\
\text { manager }\end{array}$ & TNQA counsellor \& CSR Review Committee member \\
\hline
\end{tabular}

\section{RESULTS AND ANALYSES}

\subsection{Sustainable business excellence model architecture}

In order to ensure the effectiveness of the model, two fuzzy Delphi expert questionnaires were conducted, with a recovery rate of $100 \%$. In the first round of recovered questionnaires, the quality of products/services did not converge, but the rest all showed convergence; therefore 13 items were proposed as additional items for the criteria (Table 6). The statistical results of the second round of 
questionnaires showed that all items reached convergence. Among them, five indicators were suggested to be deleted by two or more experts, and 69 effective measures were finally selected (Figure 5).

Table 6: New indicators proposed by the first expert questionnaire

\begin{tabular}{|c|c|c|}
\hline Dimension & Medium term & Indicator content \\
\hline \multirow{4}{*}{$\begin{array}{l}\text { Leadership and } \\
\text { governance }\end{array}$} & \multirow[b]{3}{*}{ Senior leadership } & 1. The moral level of leaders \\
\hline & & 2. Successor selection and cultivation plan \\
\hline & & $\begin{array}{l}\text { 3. High-level leaders adopting a work environment } \\
\text { that motivates employees and promotes continuous } \\
\text { organisational learning }\end{array}$ \\
\hline & $\begin{array}{l}\text { Governance and social } \\
\text { responsibility }\end{array}$ & $\begin{array}{l}\text { 4. Developing performance measurement indicators } \\
\text { and promoting improvement activities to achieve } \\
\text { the vision set by the organisation }\end{array}$ \\
\hline Strategic planning & Strategy execution & $\begin{array}{l}\text { 5. Planning strategies, setting goals, and } \\
\text { implementing and reviewing strategies for } \\
\text { benchmarking learning }\end{array}$ \\
\hline \multirow{4}{*}{ Customer focus } & \multirow{3}{*}{ Customer voice } & $\begin{array}{l}\text { 6. Adopting a market segmentation strategy to cater } \\
\text { to different customer groups and obtain customer } \\
\text { support }\end{array}$ \\
\hline & & $\begin{array}{l}\text { 7. Understanding the contribution of customers to } \\
\text { the company's profit }\end{array}$ \\
\hline & & 8. Analysing customers' potential purchasing power \\
\hline & Customer loyalty & $\begin{array}{l}\text { 9. Building a customer-oriented organisational } \\
\text { culture and improving customer loyalty through } \\
\text { continuous product innovation }\end{array}$ \\
\hline \multirow{2}{*}{$\begin{array}{l}\text { Measurement, analysis, } \\
\text { and knowledge } \\
\text { management }\end{array}$} & $\begin{array}{l}\text { Management of data, } \\
\text { knowledge, and } \\
\text { information technology }\end{array}$ & $\begin{array}{l}\text { 10. Encouraging the writing, reading, and quotation of } \\
\text { knowledge documents }\end{array}$ \\
\hline & $\begin{array}{l}\text { Measuring, analysing, and } \\
\text { improving performance }\end{array}$ & $\begin{array}{l}\text { 11. The organisation setting performance evaluation } \\
\text { indicators based on strategic objectives }\end{array}$ \\
\hline Employee focus & $\begin{array}{l}\text { Employee centripetal } \\
\text { force }\end{array}$ & $\begin{array}{l}\text { 12. Creating an organisational culture with channels } \\
\text { for employee motivation and open communication to } \\
\text { enhance the employees' centripetal force }\end{array}$ \\
\hline Operation management & Work flow & 13. Green supply chain management \\
\hline
\end{tabular}

\subsection{Discussion on key factors of sustainable business excellence}

\subsubsection{Correlation and causality between dimensions}

The values of the degree of correlation and the degree of cause were calculated according to the questionnaire (Table 7). In the degree of correlation, the sum of the impact and the range affecting the dimension of the achievements (17.2290) was the largest, indicating that the role of the impact range of this dimension was greater than that of the other six dimensions, mainly because an organisation's achievements and performance need to integrate all dimensions to produce a complete result. In addition, regarding cause, the value of leadership and governance (1.0954) was the largest and greater than 0 , indicating that it was a cause factor, as a company's decision-making and operation depend on the leaders' decision and governance. The result value $(-0.7288)$ was the smallest and less than 0 , indicating that it was affected more by other dimensions, and was therefore a result factor.

Table 7: Analysis of correlation degree and cause degree of the evaluation dimensions

\begin{tabular}{|c|c|c|c|c|c|c|c|c|c|c|}
\hline & A & B & C & D & $E$ & $\mathrm{~F}$ & G & $r$ value & $\begin{array}{l}\text { Correlation degree } \\
\qquad(r+d)\end{array}$ & $\begin{array}{c}\text { Cause degree } \\
(r-d)\end{array}$ \\
\hline A & 1.143 & 1.303 & 1.349 & 1.25 & 1.244 & 1.357 & 1.432 & 9.078 & *17.0610 & 1.0954 \\
\hline B & 1.177 & 1.050 & 1.232 & 1.144 & 1.106 & 1.243 & 1.312 & 8.265 & 16.3129 & 0.2173 \\
\hline C & 1.18 & 1.193 & 1.113 & 1.166 & 1.137 & 1.261 & 1.345 & 8.398 & *16.7968 & -0.0016 \\
\hline D & 1.053 & 1.061 & 1.102 & 0.931 & 1.012 & 1.133 & 1.191 & 7.480 & 15.3654 & -0.3994 \\
\hline $\mathrm{E}$ & 1.091 & 1.080 & 1.152 & 1.075 & 0.928 & 1.163 & 1.218 & 7.707 & 15.3397 & 0.0741 \\
\hline $\mathrm{F}$ & 1.158 & 1.177 & 1.222 & 1.155 & 1.107 & 1.102 & 1.312 & 8.233 & *16.7230 & -0.2570 \\
\hline G & 1.175 & 1.184 & 1.229 & 1.162 & 1.100 & 1.231 & 1.169 & 8.250 & *17.2290 & -0.7288 \\
\hline $\begin{array}{c}\mathrm{D} \\
\text { Value }\end{array}$ & 7.983 & 8.048 & 8.399 & 7.882 & 7.633 & 8.490 & 8.979 & & & \\
\hline
\end{tabular}

Note: *The dimensions marked as $(r+d)$ exceeded the threshold (16.404) 


\begin{tabular}{|c|c|c|c|}
\hline & & & $\begin{array}{l}\text { formulate an organisation's clear development vision, values and mission, and } \\
\text { organisational culture }\end{array}$ \\
\hline & & & clarify the organisation's sustainability policy \\
\hline & & & establish an internal and external multi-channel communication model \\
\hline & & & $\begin{array}{l}\text { strengthen operating performance to achieve a balanced value between customers and } \\
\text { stakeholders }\end{array}$ \\
\hline & & leadership & competitive investment returns of capital providers and protection of company assets \\
\hline & & & successor selection and cultivation plan \\
\hline & $\begin{array}{c}\text { A } \\
\text { a }\end{array}$ & & $\begin{array}{l}\text { senior leaders adopt a work environment that motivates employees and promotes } \\
\text { continuous organisational learning }\end{array}$ \\
\hline & governance & & the organisation has clear management responsibilities and diversity of members \\
\hline & & & robust finance, transparent operation, independent audit system \\
\hline & & & $\begin{array}{l}\text { the organisation operates in compliance with laws and regulations, and environmental } \\
\text { protection regulations }\end{array}$ \\
\hline & & $\begin{array}{l}\text { A2 governance } \\
\text { and social } \\
\text { responsibility }\end{array}$ & $\begin{array}{l}\text { organise the establishment of social responsibility awareness and participation in } \\
\text { activities for all. Support and improve relevant communities }\end{array}$ \\
\hline & & & formulate ethical code of conduct for anti-corruption, bribery \\
\hline & & & $\begin{array}{l}\text { promote, supervise, and maintain the standards that are followed when dealing with all } \\
\text { stakeholders }\end{array}$ \\
\hline & & & fair trade with suppliers, distributors and business partners \\
\hline & & B1 & the organisation has a set of strategic planning process \\
\hline & B & $\begin{array}{l}\text { strategy } \\
\text { development }\end{array}$ & have clear strategic goals, schedules and setting methods \\
\hline $\begin{array}{c}\text { sustainable } \\
\text { business }\end{array}$ & $\begin{array}{l}\text { strategic } \\
\text { planning }\end{array}$ & & $\begin{array}{l}\text { there are the action plan development content and goal, the necessary resources for } \\
\text { execution and the authority unit for strategy realisation }\end{array}$ \\
\hline structure & & $\begin{array}{l}\text { strategy } \\
\text { execution }\end{array}$ & $\begin{array}{l}\text { Scan the industrial environment to identify risk predictions and crisis management } \\
\text { response content }\end{array}$ \\
\hline & & & there is a future performance estimate \\
\hline & & & $\begin{array}{l}\text { the organisation has a set of methods to listen to the voices of customers, and grasp the } \\
\text { needs and expectations of customers and markets }\end{array}$ \\
\hline & & $\begin{array}{l}\text { Cl } \\
\text { customer's voice }\end{array}$ & $\begin{array}{l}\text { there are methods to accept customer complaints and opinions, and measurement } \\
\text { benchmarks to ensure customer satisfaction and participation }\end{array}$ \\
\hline & & & respect customers and provide the highest level of product and service value \\
\hline & & & understand the customer's contribution to the company's profit \\
\hline & customer focus & & analysis of customers' potential purchasing power \\
\hline & & & brand management and operation \\
\hline & & $\mathrm{C} 2$ & $\begin{array}{l}\text { product sales provide a way to meet the needs and obtain customer support and } \\
\text { participation }\end{array}$ \\
\hline & & & $\begin{array}{l}\text { establish customer relationship management methods to maintain and improve customer } \\
\text { loyalty and market share }\end{array}$ \\
\hline & & & $\begin{array}{l}\text { establish a customer-oriented organisational culture and enhance customer loyalty with } \\
\text { continuous product innovation }\end{array}$ \\
\hline & measurement, & & organise systematic performance evaluation \\
\hline & $\begin{array}{l}\text {, knowledge } \\
\text { management }\end{array}$ & $\begin{array}{l}\text { measurement, } \\
\text { analysis and }\end{array}$ & $\begin{array}{l}\text { the organisation evaluates the environmental impact, and conducts environmental life } \\
\text { cycle analysis and design according to the organisation's context }\end{array}$ \\
\hline & & performance & performance analysis and review \\
\hline & & & carry out performance improvement activities \\
\hline
\end{tabular}

Figure 5: Sustainable business excellence model 


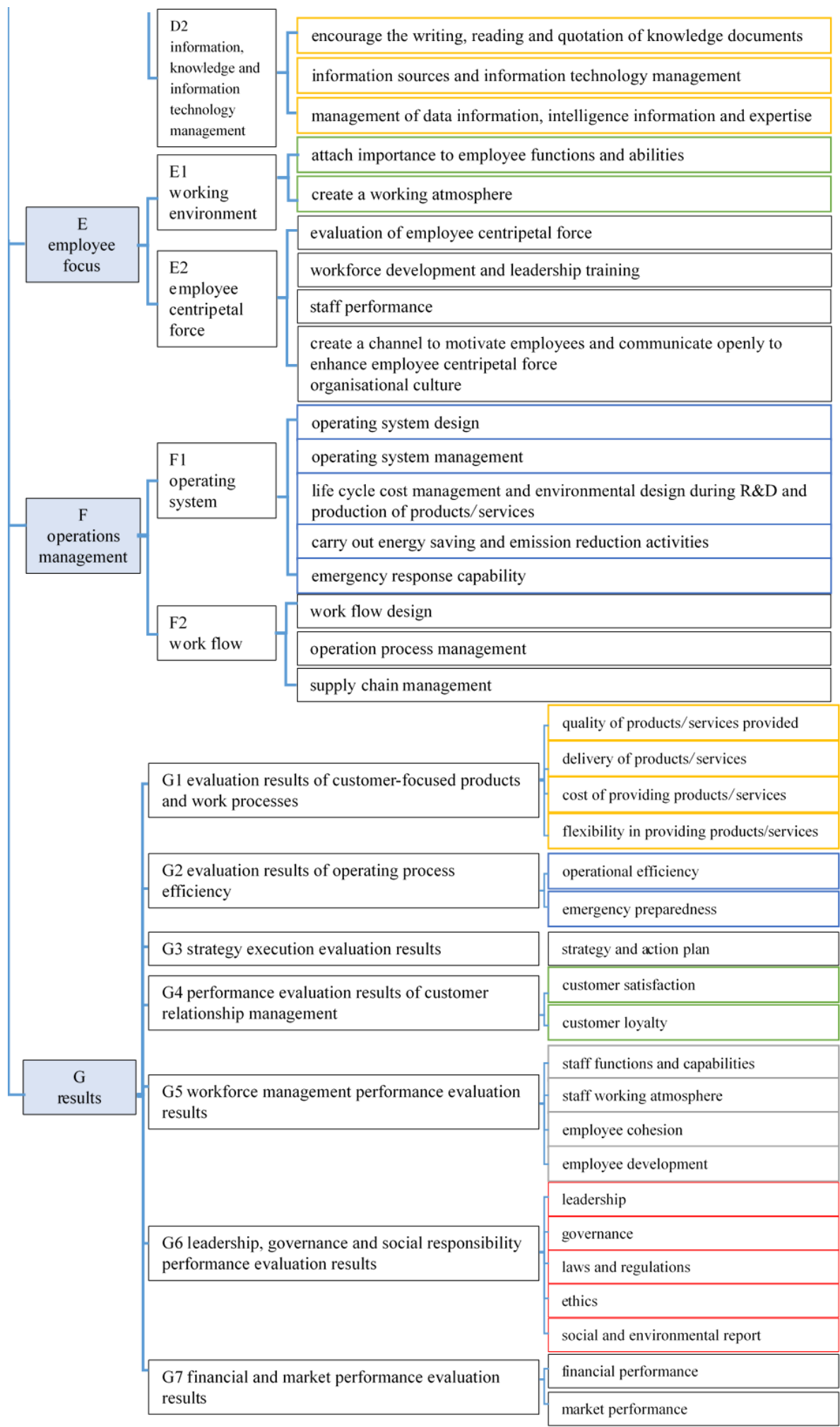

Figure 5(cont.): Sustainable business excellence model 
This study next created a cause-and-effect diagram (Figure 6). In the diagram, the four major dimensions of achievements, leadership and governance, customer focus, and operational management were located to the right of the cause and effect diagram, and had a greater number of correlations than the average of 16.404 , indicating that the scope of influence of these four dimensions was large. The calculation results of the cause degree showed that the values for leadership and governance, strategic planning, and employee focus were all greater than 0 , indicating that, when promoting sustainable business excellence management, special attention should be given to the development of these three dimensions.

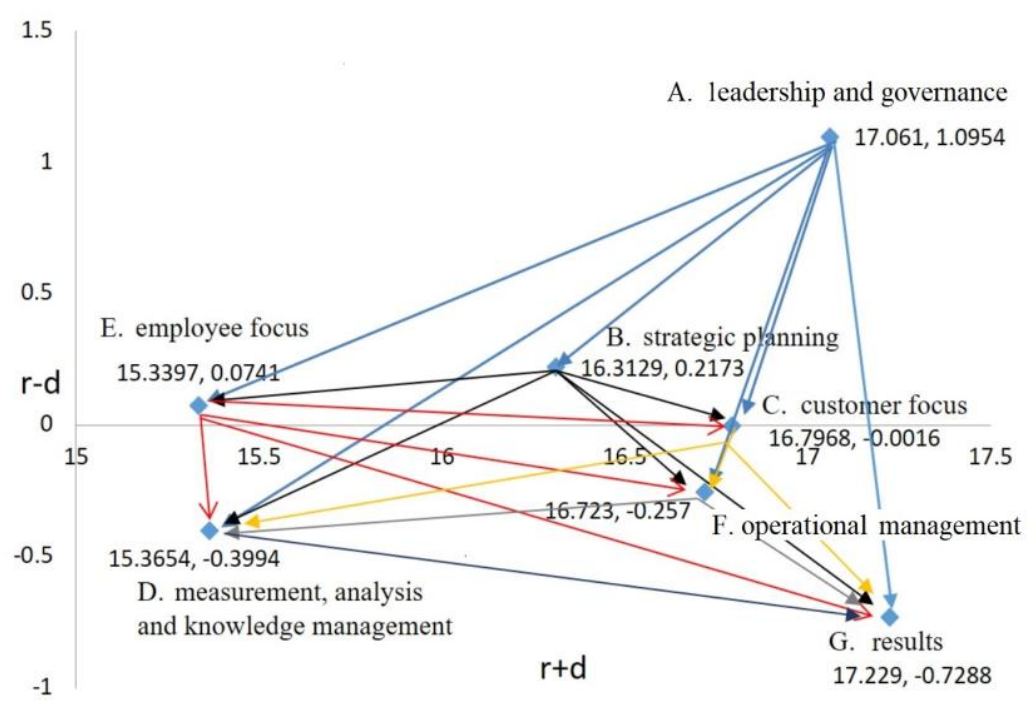

Figure 6: Seven dimensions of the sustainable business excellence model

\subsubsection{Second-order factor layer correlation and causality}

According to the relationship table of the second-order factor influence degree (Table 8 ), the first three items for cause degree were high-level leadership (0.734), working environment (0.609), and governance and social responsibility (0.426). Among them, high-level leadership was relatively larger than the other items, indicating that it was one of the important influencing factors of the other items. The top three items for the correlation degree were high-level leadership (18.881), financial and market performance evaluation results (18.391), and customer voice (18.288), indicating that these three items were highly involved with the other items. Among them, high-level leaders ranked first in terms of influence and correlation, indicating that its importance was very high in this sustainable business excellence model.

Table 8: Influence degree relationship of second-order factors

\begin{tabular}{|c|c|c|c|c|c|c|c|}
\hline Dimension & $\begin{array}{l}\text { Medium- } \\
\text { term criteria }\end{array}$ & $r+d$ & $r-d$ & Dimension & $\begin{array}{l}\text { Medium-term } \\
\text { criteria }\end{array}$ & $r+d$ & $r-d$ \\
\hline \multirow{2}{*}{ A } & $\mathrm{A} 1$ & *18.881 (1) & $0.734(1)$ & \multirow{2}{*}{$F$} & F1 & $17.489(14)$ & $-0.285(14)$ \\
\hline & $\mathrm{A} 2$ & 17.415(15) & $0.426(3)$ & & F2 & 17.694(13) & $-0.479(19)$ \\
\hline \multirow{2}{*}{ B } & B1 & ${ }^{*} 17.827(11)$ & $0.108(8)$ & \multirow{7}{*}{ G } & G1 & ${ }^{*} 18.170(6)$ & $-0.170(12)$ \\
\hline & B2 & ${ }^{*} 18.163(7)$ & $0.022(9)$ & & G2 & *18.017(9) & $-0.370(16)$ \\
\hline \multirow{2}{*}{ C } & $\mathrm{C} 1$ & ${ }^{*} 18.288(3)$ & $0.191(5)$ & & G3 & *18.029(8) & $-0.179(13)$ \\
\hline & $\mathrm{C2}$ & *17.748(12) & $-0.008(10)$ & & G4 & *18.202(4) & $-0.447(18)$ \\
\hline \multirow{2}{*}{ D } & D1 & ${ }^{*} 17.866(10)$ & $-0.320(15)$ & & G5 & $17.243(16)$ & $0.136(7)$ \\
\hline & D2 & 15.612(19) & $-0.141(11)$ & & G6 & *18.175(5) & $0.180(6)$ \\
\hline \multirow{2}{*}{$E$} & E1 & $16.078(18)$ & $0.609(2)$ & & G7 & *18.391(2) & $-0.425(17)$ \\
\hline & E2 & $16.922(17)$ & $0.417(4)$ & & & & \\
\hline
\end{tabular}

Note: $1 .^{*}$ The dimensions marked as $(r+d)$ exceeding the threshold (17.695)

2. The values in brackets are ranked from high to low.

\section{CONCLUSION}

In the face of today's increasingly competitive environment, environmental change, and high international requirements to address green environmental issues, companies must also consider the sustainability of society and the environment while pursuing economic efficiency to enjoy long-term 
growth and create competitive advantages. By integrating the valuable opinions of experts and scholars from the same domain, this study developed a sustainable business excellence model that was suitable for corporate organisations. This framework consisted of the integration of seven major dimensions of business excellence with environmental and social dimensions to develop 69 detailed indicators.

Complex causal relationships among the seven dimensions were highlighted in the discussion of the key factors. The numerical calculation results of the cause degree showed that the values of leadership and governance, strategic planning, and employee focus were all greater than 0 , indicating that the development of these three dimensions should be given special attention when promoting sustainable business excellence. The value of leadership and governance was much greater than of the other dimensions, showing its importance and influence. It could be seen that leadership and governance is the most important key factor when companies promote sustainable business excellence models. The values of the correlations among the four dimensions of achievements, leadership and governance, customer focus, and operation management were greater than the threshold value set by the arithmetic mean of the degree of correlation, indicating that these four dimensions had a greater range of influence. The value of the achievement dimension was the largest, indicating that it was most related to the other dimensions and that the achievements of an organisation/enterprise are related to all the dimensions of an organisation. The values of the cause degree of the dimensions of customer focus, operation management, measurement, analysis and knowledge management, and achievements were all less than 0 , indicating that they tended to be the affected factors. Among them, the value of the achievements dimension was much smaller than those of the other values, indicating that it was affected by the other six dimensions.

According to the relation table of the medium-term factors, the first three items of the cause value were high-level leadership, working environment, and governance and social responsibility. Among them, the value of high-level leadership was relatively larger than those of the other items, indicating that it was an important influence factor for the other items. When promoting sustainable business excellence, corporate organisations should focus on high-level leadership, create a clear organisational culture, and clarify the company's policies and vision. They should establish internal and external communication channels, and keep all the stakeholders on the same page. The second priority is the emphasis on the work environment. The most important assets and operational members of an organisation are its employees; thus creating a good working atmosphere and focusing on employee functions and capabilities are key. The third priority is governance and social responsibility. A company that takes social responsibility seriously and builds a transparent system will improve its management and social evaluation and further enhance its added value.

The first three items in the correlation value were high-level leadership, financial and market performance evaluation results, and customer voice, which indicated that these three items were highly related to the other items. Among them, high-level leadership ranked first in both the degree of influence and the degree of correlation, indicating that its importance was quite high in this sustainable business excellence model, which was a key factor. The results of the financial and market performance evaluation were the results of the overall operation of the organisation; therefore the degree of correlation was high. It also showed that all operations in an organisation are ultimately related to financial and market performance. The basic focus in TQM is having a customer orientation. The market is driven by the voice of the customer; and the importance of the voice of the customer is also shown in the degree of correlation.

This research was a preliminary study, and the overall structure was mainly evaluated by experts in industry, government, learning, and research. It is recommended that subsequent researchers import the evaluation structure proposed in this study into different industries, and conduct enterprise empirical research to prove that this research outcome can be applied broadly.

\section{REFERENCES}

[1] Senge, P.M., Smith, B., Kruschwitz, N., Laur, J. \& Schley, S. 2008. The necessary revolution: How individuals and organizations are working together to create a sustainable world. $1^{\text {th }}$ ed. New York: Crown Business.

[2] Epstein, M.J. 2014. Making sustainability work: Best practices in managing and measuring corporate social, environmental, and economic impacts. $2^{\text {th }}$ ed. Sheffield: Greenleaf Publishing.

[3] Hawken, P., Lovins, A.B. \& Lovins, L.H. 1999. Natural capitalism: Creating the next industrial revolution. $1^{\text {th }}$ ed. New York: Little, Brown \& Company. 
[4] Elkington, J. 1997. Cannibals with forks: The triple bottom line of 21st century business. $1^{\text {th }}$ ed. Oxford: Capstone.

[5] Fauzi, H., Svensson, G. \& Abdul-Rahman, A. 2010. Triple bottom line as sustainable corporate performance: A proposition for the future. Sustainability, 2, pp. 1345-1360.

[6] Yang, C.C. 2003. The establishment of a TQM system for the health care industry. The TQM Magazine, 15(2), pp. 93-98.

[7] Fu, S.L., Chou, S.Y., Chen, C.K. \& Wang, C. W. 2015. Assessment and cultivation of total quality management organisational culture: An empirical investigation. Total Quality Management \& Business Excellence, 26(2), pp. 123-139.

[8] Tarí, J.J. \& García, M.G. 2011. La gestión de la calidad y la responsabilidad social en empresas de servicios. Revista de Direccióny Administración de Empresas, 18, pp. 77-94.

[9] Benavides-Velasco, C.A., Quintana-García, C. \& Marchante-Lara, M. 2014. Total quality management, corporate social responsibility and performance in the hotel industry. International Journal of Hospitality Management, 41, pp. 77-87.

[10] McAdam, R. \& Leonard, D. 2003. Corporate social responsibility in a total quality management context: Opportunities for sustainable growth. Corporate Governance: The International Journal of Business in Society, 3(4), pp. 36-45.

[11] Withanachchi, N., Handa, Y., Karandagoda, K.K.W., Pathirage, P.P., Tennakoon, N.C.K. \& Pullaperuma, D.S.P. 2007. TQM emphasizing 5-S principles: A breakthrough for chronic managerial constraints at public hospitals in developing countries. International Journal of Public Sector Management, 20(3), pp. 168-177.

[12] Zink, K.J. 2007. From total quality management to corporate sustainability based on a stakeholder management. Journal of Management History, 13(4), pp. 394-401.

[13] Curkovic, S. 2003. Environmentally responsible manufacturing: The development and validation of a measurement model. European Journal of Operational Research, 146(1), pp. 130-155.

[14] Hamner, B. 1996. What is the relationship between cleaner production, pollution prevention, waste minimization and ISO 14000? First Asian Conference on Cleaner Production in Chemical Industry, December 9-10. Taipei, Taiwan.

[15] Hart, L. \& Milstein, M.B. 2003. Creating sustainable value. Academy of Management Perspectives, 17(2), pp. 56-69.

[16] Dyllick, T. \& Hockerts, K. 2002. Beyond the business case for corporate sustainability. Business Strategy and the Environment, 11(2), pp. 130-141.

[17] Camejo, P. 2002. The SRI advantage: Why socially responsible investing has outperformed financially. $1^{\text {th }}$ ed. British Columbia: New Society.

[18] Curkovic, S., Melnyk, S. \& Calantone, R. 2000. Validating the Malcolm Baldrige National Quality Award framework through structural equation modelling. International Journal of Production Research, 38(4), pp. 765-791.

[19] Bohoris, G.A. 1995. A comparative assessment of some major quality awards. International Journal of Quality \& Reliability Management, 12(9), pp. 30-43.

[20] Ghobadian, A. \& Woo, H.S. 1996. Characteristics, benefits and shortcomings of four major quality awards. International Journal of Quality and Reliability Management, 13(2), pp. 10-44.

[21] Yong, J. \& Wilkinson, A. 2001. Rethinking total quality management. Total Quality Management, 12(2), pp. 247-258.

[22] Blazey M.L. 2007. Insights to performance excellence 2007: An inside look at the 2007 Baldrige Award criteria. $1^{\text {th }}$ ed. Milwaukee: ASQ Quality Press.

[23] NIST. 2013. 2013 2014 Criteria for performance excellence. $1^{\text {th }}$ ed. Gaithersburg: NIST.

[24] Hakes, C. 2007. The EFQM excellence model to assess organizational performance: $A$ management guide (best practice). $1^{\text {th }}$ ed. 's-Hertogenbosch: Van Haren.

[25] JPC. 2008. Japan quality award assessment guide book, $3^{\text {th }}$ ed. Tokyo: JQAC.

[26] Dow Jones sustainability indexes (DJSI). 2011. Available from:

http: / / www.sustainability-

index.com/djsi_pdf/publications/Guidebooks/DJSI_World_Guidebook_11\%206_final.pdf. [Accessed on May 25, 2011].Jeng T.B. 2001. Fuzzy assessment model for maturity of software organization in improving its staff's capability. Master's thesis, Department of Information Management, School of Management, National Taiwan University of Science and Technology, Taipei, Taiwan.

[27] Tzeng, G.H., Chiang, C.H. \& Li, C.W. 2007. Evaluating intertwined effects in e-learning programs: A novel hybrid MCDM model based on factor analysis and DEMATEL. Expert Systems with Applications, 32(4), pp. 1028-1044. 